\title{
HUBUNGAN DUKUNGAN KELUARGA DENGAN TINGKAT DEPRESI PADA LANSIA
}

\author{
Budi Kristanto', Rika Fitri Agustina²
}

\begin{abstract}
Background: The incidence of depression in elderly people in Indonesia is currently high. Indonesia has entered the era of elderly population. In 2009, the number of people aged over 60 years about $7.18 \%$. Depression is a major mental health problem today. This is very important because the incidence of depression will badly affects the productivity of people particulary in a developing society.

Research purposes : This research was generally aimed to find out the relationship between family support and depression level in elderly as well as specifically to identify family support for elderly and identify depression level in elderly.

Subject : Research respondents were elderly people aged 60 years and over in Telukan Village Sukoharjo District.

Method : This research is a correlation research with cross sectional approach to analyze the relationship betwen family support with depression level in elderly in Telukan Village Sukoharjo District. In this study the researcher used a saturated sampling technique in which all members of the population was used as a research respondent accounted for 60.

Research result : The majority of respondents who good support from their family was $58.3 \%$ while the rest $41.7 \%$ got less support. The majority of were normal category ( $80 \%)$ while those with mild depression by $20 \%$. The results of analysis with Pearson Correlation obtained $p$ value $=0.000$ and value $r=-0.559$.

Conclusion : There is a significant relationship between family support and the incidence of depression in the elderly. The higher the family support the lower the incidence of depression in the elderly.
\end{abstract}

Keywords: depression, family support, elderly

\section{PENDAHULUAN}

Angka kejadian depresi pada lansia di Indonesia saat ini tergolong tinggi, menurut Irawan (2013), saat ini Indonesia telah memasuki era penduduk struktur lansia karena tahun 2009 jumlah penduduk berusia di atas 60 tahun sekitar $7.18 \%$. Provinsi yang mempunyai jumlah penduduk lansia sekitar 7\% adalah di Jawa dan Bali. Jumlah penduduk lansia pada tahun 2006 sebesar kurang lebih 19 juta dengan usia harapan hidup 67.4 tahun, pada tahun 2020 diperkirakan sebesar 28.8 juta (11.34\%) dengan usia harapan hidup 71.1 tahun. Seiring bertambahnya usia, penuaan tidak dapat dihindarkan dan terjadi perubahan keadaan fisik, selain itu para lansia mulai kehilangan pekerjaan, kehilangan tujuan hidup, kehilangan teman, risiko terkena penyakit, terisolasi dari lingkungan, dan kesepian. Hal tersebut dapat memicu terjadinya gangguan mental. Depresi merupakan salah satu gangguan mental yang banyak dijumpai pada lansia akibat proses penuaan. Berdasarkan data di Canada 5-10\% lansia yang hidup dalam komunitas mengalami depresi, sedangkan yang hidup dalam lingkungan institusi $30-40 \%$ mengalami depresi dan cemas. Depresi menurut WHO (World Health Organization) merupakan suatu gangguan mental umum yang ditandai dengan mood tertekan, kehilangan kesenangan atau minat, perasaan bersalah atau harga diri rendah, gangguan makan 
atau tidur, kurang energi, dan konsentrasi yang rendah. Masalah ini dapat akut atau kronik dan menyebabkan gangguan kemampuan individu untuk beraktivitas sehari-hari.

Depresi merupakan masalah kesehatan jiwa yang utama dewasa ini. Hal ini amat penting karena orang dengan depresi produktivitasnya akan menurun dan ini amat buruk akibatnya bagi suatu masyarakat, bangsa dan negara yang sedang membangun. Orang yang mengalami depresi adalah orang yang amat menderita. Depresi adalah penyebab utama tindakan bunuh diri, dan tindakan ini menduduki urutan ke enam dari penyebab kematian utama di Amerika Serikat (Hawari, 2016).

Menurut Maryam, et al. (2008), lanjut usia adalah seseorang yang telah mencapai usia lebih dari 60 tahun. Salah satu masalah kesehatan jiwa yang paling sering didapatkan pada lansia adalah depresi. Sebagaimana dikutip oleh Widyanto (2014), lanjut usia atau lansia merupakan individu yang berada dalam tahapan usia late adulthood atau yang dimaksud dengan tahapan usia dewasa akhir, dengan kisaran usia dimulai dari 60 tahun ke atas. Setiap individu mengalami proses penuaan (aging) yang terbagi menjadi dua yaitu penuaan primer dan sekunder. Penuaan primer adalah proses deteriorasi tubuh yang sifatnya bertahap, tidak terhindarkan, dan umum dialami manusia. Penuaan sekunder mengarah pada proses yang mempengaruhi tingkat penuaan primer, sebagai akibat dari suatu kondisi penyakit, pemaparan lingkungan fisik yang tidak sehat, dan juga penyalahgunaan yang termasuk di dalam kontrol manusia seperti stres di tempat kerja, paparan racun di lingkungan, dan lain sebagainya.
Seiring dengan proses menua tersebut, tubuh akan mengalami berbagai masalah kesehatan atau yang biasa disebut sebagai penyakit degeneratif. Proses menua yang dialami oleh lansia menyebabkan mereka mengalami berbagai macam perasaan seperti sedih, cemas, kesepian, dan mudah tersinggung. Perasaan tersebut merupakan masalah jiwa yang terjadi pada lansia. Masalah gangguan kesehatan jiwa mulai dialami oleh golongan lansia pada saat mereka mulai merasakan adanya tandatanda terjadinya proses penuaan pada dirinya. Jika lansia mengalami masalah gangguan kesehatan jiwa, maka kondisi tersebut dapat menganggu kegiatan sehari-hari lansia. Mencegah dan merawat lansia dengan masalah kesehatan jiwa adalah hal yang sangat penting dalam upaya mendorong lansia bahagia dan sejahtera di dalam keluarga serta masyarakat. Kondisi mental yang sehat dan aktif pada masa tua dibutuhkan pemeliharaan yang kontinyu untuk mempertahankan daya pikirnya dan mencegah dari perasaan cemas dan depresi (Maryam, et al., 2008).

Sebagaimana dikutip oleh Setiadi (2008), dukungan adalah suatu keadaan yang bermanfaat bagi individu yang diperoleh dari anggota keluarga yang dapat dipercaya, sehingga seseorang akan tahu bahwa ada keluarga lain memperhatikan, menghargai dan mencintainya. Keluarga merupakan support system utama bagi lansia dalam mempertahankan kesehatannya. Peranan keluarga dalam perawatan lansia antara lain menjaga atau merawat lansia, mempertahankan dan meningkatkan status mental, mengantisipasi perubahan sosial ekonomi, serta memberikan motivasi dan memfasilitasi kebutuhan spiritural bagi lansia. Keluarga dijadikan sebagai unit pelayanan karena 
masalah kesehatan keluarga saling berkaitan dan saling mempengaruhi antara sesama anggota keluarga dan akan mempengaruhi pula keluarga-keluarga di sekitarnya (Setiadi, 2008).

Penelitian Permana (2013), menyatakan terdapat hubungan antara dukungan sosial keluarga dan tingkat stres pada andropause lansia di Puskesmas Patrang, Jember dengan nilai $p$ adalah 0.000 $<0.05$. Penelitian Prabowo (2016), mendapatkan hasil bahwa ada perbedaan tingkat depresi lansia wanita yang tinggal bersama keluarga di Kelurahan Wirogunan dengan tinggal di Panti Wredha Hanna Yogyakarta, $p$-value $=0.033$ $(<0.05)$, dimana lansia wanita yang tinggal dengan keluarga memiliki tingkat depresi yang lebih rendah. Penelitian Kurniasari (2014), yang berjudul "Faktor-Faktor yang Berhubungan dengan Depresi pada Lansia di Dusun Kalimanjing Amnar Ketawang Gamping Sleman Yogyakarta", diperoleh hasil bahwa umur, jenis kelamin, status perkawinan, dan fungsi kognitif mempunyai korelasi dengan depresi pada lansia di kampung Kalimanjung, Ambarketawang, Gamping, Sleman, Yogyakarta. Penelitian lain yang dilakukan Marchira dan Wirasto (2007) yang berjudul "Pengaruh Faktor-Faktor Psikososial dan Insomnia terhadap Depresi pada Lansia di Kota Yogyakarta" diperoleh hasil bahwa dukungan sosial adalah salah satu faktor yang paling penting pada kejadian depresi di kalangan lansia.

Menurut Maryam, et al., (2008), tugas perkembangan keluarga merupakan tanggung jawab yang harus dicapai oleh keluarga dalam setiap tahap perkembangannya. Keluarga diharapkan dapat memenuhi kebutuhan biologis, imperatif (saling menguatkan), budaya dan aspirasi, serta nilai-nilai keluarga. Selain itu lansia sendiri harus dapat melakukan perawatan dirinya sendiri, keluarga, dan orangorang disekitarnya pun perlu memahami bagaimana melakukan perawatan yang tepat bagi lansia tersebut.

Berdasarkan pengamatan yang dilakukan peneliti, lansia yang berada di Desa Telukan Kabupaten Sukoharjo banyak yang ketika memasuki masa lansia merasa kesepian karena berada jauh dari anak, sedangkan dengan bertambahnya usia menyebabkan kemunduran fungsi fisik yang akan mengakibatkan tingginya tingkat depresi pada lansia. Dari pengamatan penulis pada 3 orang lansia, 2 orang lansia jauh dari keluarga, 1 orang lansia tinggal dengan keluarga. Didapatkan hasil bahwa 2 orang lansia yang jauh dari keluarga merasakan adanya gejala depresi berupa kehilangan minat, konsentrasi dan daya ingat menurun, mudah lelah saat beraktivitas, sedangkan 1 orang lansia yang tinggal dengan keluarga tidak mengalami gejala depresi yang dirasakan pada lansia yang jauh dari keluarga.

Berdasarkan uraian latar belakang di atas, maka peneliti tertarik untuk melakukan penelitian tentang hubungan dukungan keluarga dengan tingkat depresi pada lansia di Desa Telukan Kabupaten Sukoharjo.

Penelitian ini merupakan replika dari penelitian sebelumnya, akan tetapi dengan karakteristik responden dan lokasi yang berbeda yaitu di lingkungan pedesaan.

\section{TUJUAN PENELITIAN}

Penelitian ini secara umum bertujuan untuk mengetahui hubungan antara dukungan keluarga dengan tingkat depresi pada lansia serta secara khusus untuk mengidentifikasi dukungan keluarga terhadap lansia dan 
mengidentifikasi tingkat depresi pada lansia.

\section{METODE/DESAIN PENELITIAN}

Penelitian ini merupakan penelitian korelasi dengan pendekatan cross sectional untuk mengetahui hubungan dukungan keluarga dengan tingkat depresi pada lansia di Desa Telukan Kabupaten Sukoharjo. Responden penelitian adalah lansia yang berusia 60 tahun ke atas, pengambilan sampel penelitian ini menggunakan teknik sampling jenuh dimana seluruh anggota populasi dipakai sebagai responden penelitian yaitu sejumlah 60 orang.

\section{HASIL PENELITIAN}

Didapatkan karakteristik responden berdasarkan umur, jenis kelamin dan pendidikan beserta hasil penelitian mengenai hubungan dukungan keluarga dengan tingkat depresi pada lansia adalah sebagai berikut :

Tabel 1.

Distribusi Frekuensi Karakteristik Responden

\begin{tabular}{lcc}
\hline \multicolumn{1}{c}{ Karakteristik } & $f$ & $\%$ \\
\hline $\begin{array}{l}\text { Jenis Kelamin } \\
\text { Laki-laki }\end{array}$ & 28 & 46.7 \\
Perempuan & 32 & 53.3 \\
Usia & & \\
$61-65$ & 28 & 46.7 \\
$66-70$ & 12 & 20 \\
$71-75$ & 6 & 10 \\
$>75$ & 14 & 23.3 \\
Pendidikan & & \\
Tidak sekolah & 24 & 40 \\
SD & 13 & 21.7 \\
SMP & 16 & 26.7 \\
SMA/SMK & 7 & 11.6 \\
PT & 0 & 0 \\
\hline
\end{tabular}

Dari tabel di atas dapat diperoleh informasi bahwa mayoritas responden $(53.3 \%)$ berjenis kelamin perempuan, mayoritas usia rentang 61-65 (46.7\%). Sedangkan berdasarkan tingkat pendidikan mayoritas responden (40\%) tidak sekolah.

Tabel 2.

Distribusi Frekuensi Responden Berdasarkan Orang yang Tinggal Bersama dalam Satu Rumah

\begin{tabular}{ccc}
\hline Karakteristik Responden & $\mathrm{f}$ & $\%$ \\
\hline Tinggal dengan keluarga & & \\
Ya & 57 & 95 \\
Tidak & 3 & 5 \\
Masih ada pasangan & & \\
Ya & 40 & 66.7 \\
Tidak & 20 & 33.3 \\
\hline
\end{tabular}

Dari tabel di atas diperoleh informasi bahwa mayoritas responden tinggal bersama dengan keluarga (95\%), dan mayoritas masih memiliki pasangan yang masih hidup $(66.7 \%)$.

Tabel 3.

Distribusi Frekuensi Kategori Depresi

\begin{tabular}{ccc}
\hline Kategori & $f$ & $\%$ \\
\hline Normal & 48 & 80 \\
Ringan & 12 & 20 \\
Berat & 0 & 0 \\
\hline Jumlah & 60 & 100 \\
\hline
\end{tabular}

Dari tabel di atas dapat diperoleh bahwa mayoritas responden dalam kategori normal sebesar $80 \%$, sedangkan yang mengalami depresi ringan sebesar $20 \%$.

Tabel 4.

Distribusi Frekuensi Kategori Dukungan Keluarga

\begin{tabular}{ccc}
\hline Kategori & $\mathrm{f}$ & $\%$ \\
\hline Baik & 35 & 58.3 \\
Kurang & 25 & 41.7 \\
\hline Jumlah & 60 & 100 \\
\hline
\end{tabular}


Dari tabel di atas terlihat bahwa mayoritas responden dengan dukungn keluarga kategori baik yaitu $58.3 \%$ sedangkan $41.7 \%$ dengan dukungan yang kurang.

Tabel 5.

Tabulasi Silang Kejadian Depresi dengan Dukungan Keluarga

\begin{tabular}{cccc}
\hline \multirow{2}{*}{$\begin{array}{c}\text { Kategori } \\
\text { Depresi }\end{array}$} & \multicolumn{2}{c}{$\begin{array}{c}\text { Kategori } \\
\text { Dukungan }\end{array}$} & Total \\
\cline { 2 - 3 } & Baik & Kurang & \\
\hline Normal & 33 & 15 & 48 \\
$\begin{array}{c}\text { Depresi } \\
\text { Ringan }\end{array}$ & 2 & 10 & 12 \\
\hline Total & 35 & 25 & 60 \\
\hline
\end{tabular}

Dari tabulasi silang antara kategori depresi dengan kategori dukungan keluarga diperoleh hasil bahwa terdapat responden normal dengan dukungan keluarga baik sejumlah 33 (55\%), responden normal dengan dukungan keluarga kurang sejumlah 15 (25\%). Sedangkan responden dengan depresi ringan dengan dukungan baik sejumlah 2 (3.33\%) dan depresi ringan dengan dukungan keluarga kurang sejumlah $10(16.67 \%)$.

Hasil analisis dengan SPSS 16 For Windows diperoleh hasil analisis menggunakan Pearson Corelation diperoleh nilai nilai $p=0.000$, yang berarti terdapat hubungan antara dukungan keluarga dengan kejadian depresi pada lansia. Diperoleh nilai $r$ $=-0.559$ yang berarti memiliki korelasi yang kuat dan memberikan makna berkebalikan dari variabel yang berarti semakin tinggi dukungan keluarga maka semakin rendah kejadian depresi pada lansia atau sebaliknya semakin rendah dukungan keluarga semakin tinggi kejadian depresi pada lansia.

\section{PEMBAHASAN}

Angka kejadian depresi pada lansia di Indonesia saat ini tergolong tinggi, menurut Irawan (2013), saat ini Indonesia telah memasuki era penduduk struktur lansia karena tahun 2009 jumlah penduduk berusia di atas 60 tahun sekitar $7.18 \%$. Jumlah penduduk lansia pada tahun 2006 sebesar kurang lebih 19 juta dengan usia harapan hidup 67.4 tahun, pada tahun 2020 diperkirakan sebesar 28.8 juta (11.34\%) dengan usia harapan hidup 71.1 tahun. Seiring bertambahnya usia, penuaan tidak dapat dihindarkan dan terjadi perubahan keadaan fisik, selain itu para lansia mulai kehilangan pekerjaan, kehilangan tujuan hidup, kehilangan teman, risiko terkena penyakit, terisolasi dari lingkungan, dan kesepian. Hal tersebut dapat memicu terjadinya gangguan mental.

Depresi merupakan masalah kesehatan jiwa yang utama dewasa ini. Hal ini amat penting karena orang dengan depresi produktivitasnya akan menurun dan ini amat buruk akibatnya bagi suatu masyarakat, bangsa dan negara yang sedang membangun. Orang yang mengalami depresi adalah orang yang amat menderita. Depresi adalah penyebab utama tindakan bunuh diri, dan tindakan ini menduduki urutan keenam dari penyebab kematian utama di Amerika Serikat (Hawari, 2016).

Depresi merupakan suatu kelainan alam perasaan berupa hilangnya minat atau kesenangan dalam aktivitas - aktivitas yang biasa dilakukan sehari - hari dan pada waktu yang lampau rentang respon emosi individu dapat berfluktuasi dalam rentang respon emosi dari adaptif sampai mal adaptif. Respon emosi yang mal adaptif berat dan dapat dikenal melalui intensitas, rembetan, terus - menerus dan 
pengaruhnya pada fungsi sosial dan fisik individu (Priyoto, 2014).

Pada penelitian ini diperoleh informasi pada tabel 3, bahwa 12 responden (20\%) mengalami depresi ringan, sedangkan $80 \%$ dalam keadaan normal atau tidak dalam kategori depresi.

Angka kejadian depresi $20 \%$ pada penelitian ini termasuk angka kejadian yang cukup tinggi dan perlu mendapatkan perhatian serta intervensi yang baik dari pihak yang terkait walaupun masih dalam kategori depresi ringan. Menurut Maslim (1997) sebagaimana dikutip oleh Aspiani (2014), tingkatan depresi ringan dapat dilihat adanya gejala : kehilangan minat dan kegembiraan, berkurangnya energi yang menuju meningkatnya keadaan mudah lelah (rasa lelah yang nyata sesudah kerja sedikit saja) dan menurunnya aktivitas, konsentrasi dan perhatian yang kurang, harga diri dan kepercayaan diri yang kurang. Lamanya gejala tersebut berlangsung sekurangkurangnya 2 minggu. Hanya sedikit kesulitan dalam pekerjaan dan kegiatan sosial yang biasa dilakukannya. Berdasarkan uraian tanda gejala depresi ringan tersebut maka masih cukup mudah untuk memberikan intervensi sebelum berlanjut pada tingkatan depresi sedang ataupun depresi berat.

Sebagaimana dikutip oleh Aspiani (2014), apabila depresi masuk dalam tingkatan depresi sedang, maka akan diperoleh berbagai gejala lanjutan. Akan muncul gejala kehilangan minat dan kegembiraan, berkurangnya energi yang menuju meningkatnya keadaan mudah lelah (rasa lelah yang nyata sesudah kerja sedikit saja) dan menurunnya aktivitas, konsentrasi dan perhatian yang kurang, harga diri dan kepercayaan diri yang kurang, gagasan tentang rasa bersalah dan tidak berguna, pandangan masa depan yang suram dan pesimistis, lamanya gejala tersebut berlangsung minimum sekitar 2 minggu. Apabila pada tahap ini tidak terdeteksi dan tidak mendapatkan penanganan yang tepat maka akan berlanjut pada tahap depresi berat. Adapun gejala tambahannya meliputi, lansia memiliki pemikiran tentang rasa bersalah dan tidak berguna, pandangan masa depan yang suram dan pesimistis, perbuatan yang membahayakan dirinya sendiri atau bunuh diri, tidur terganggu, dapat disertai waham, halusinasi. Lamanya gejala tersebut juga berlangsung selama 2 minggu.

Pengenalan akan tanda gejala depresi tersebut di atas perlu diketahui oleh tenaga kesehatan bahkan perlu upaya kolaboratif dengan keluarga. Keluarga yang mengetahui secara lengkap terkait dengan keadaan lansia. Selain itu peran dari lingkungan sekitar tempat tinggal lansia juga sangat penting, terlebih untuk lansia yang hanya tinggal sendiri, dan jauh dari keluarganya, apalagi lansia yang sudah kehilangan pasangannya.

Pada penelitian ini diperoleh informasi bahwa $33.3 \%$ responden sudah tidak memiliki pasangan (janda/duda). Jadi masing-masing responden sudah kehilangan pasangan hidupnya, seperti yang dikemukakan Padila (2013), pasangan hidup adalah seseorang yang paling dekat dan memberikan dukungan psikologis bagi seorang lansia, kehilangan pasangan hidup berarti kehilangan orang terdekat yang memberikan dukungan dan semangat. Salah satu faktor yang mempengaruhi keadaan psikologis dari seorang lansia adalah kehilangan pasangan hidup.

Pada penelitian ini diperoleh data pada tabel 4 bahwa mayoritas responden dengan dukungn keluarga kategori baik yaitu $58.3 \%$ sedangkan $41.7 \%$ dengan dukungan yang kurang. Angka yang perlu mendapatkan perhatian disini 
adalah $41.7 \%$ responden dengan dukungan yang kurang. Sebagaimana dikutip oleh Setiadi (2008), dukungan keluarga adalah sikap, tindakan dan penerimaan keluarga terhadap anggotanya. Anggota keluarga memandang bahwa orang yang bersifat mendukung selalu siap memberikan pertolongan dan bantuan jika diperlukan.

Dari hasil penelitian ini $41.7 \%$ lansia dengan dukungan keluarga yang kurang. Dukungan yang kurang yang diperoleh pada penelitian ini berupa keluarga jarang menanyakan tentang kesehatan lansia, keluarga jarang mengunjungi, keluarga kurang mendengarkan keluh kesah lansia dengan baik. Dari uraian tersebut sebenarnya banyak hal yang nampaknya sederhana yang bisa keluarga lakukan yang dapat memberikan dukungan kepada lansia baik fisik maupun psikologis.

Menurut Setiadi (2008), wujud dukungan keluarga: adalah sebagai kolektor dan disseminator informasi tentang dunia. Manfaatnya dapat menahan munculnya suatu stressor karena informasi yang diberikan dapat menyumbangkan aksi sugesti yang khusus pada individu. Aspekaspek dalam dukungan ini adalah nasehat, usulan, saran, petunjuk dan pemberian informasi. Keluarga bertindak sebagai sebuah bimbingan umpan balik, membimbing dan menengahi pemecahan masalah serta sebagai sumber dan validator identitas keluarga, diantaranya adalah memberikan support, penghargaan dan perhatian. Keluarga bertindak sebagai sumber pertolongan praktis dan konkrit. Dukungan instrumen diantaranya adalah kesehatan dalam hal makan, minum, istirahat dan terhindarnya dari kelelahan.

Menurut Setiadi (2008), keluarga sebagai tempat yang aman dan damai untuk istirahat dan pemulihan serta membantu penguasaan terhadap emosi diantaranya menjaga hubungan emosional, perasaan aman, nyaman dan terlindung, serta hubungan interpersonal. Aspek-aspek dari dukungan emosional meliputi dukungan yang diwujudkan dalam bentuk afeksi, adanya kepercayaan, perhatian dan mendengarkan atau didengarkan. Dukungan sosial keluarga merupakan sebuah proses yang terjadi sepanjang masa kehidupan, sifat dan jenis dukungan sosial berbeda-beda dalam berbagai tahap-tahap siklus kehidupan. Dalam semua tahap kehidupan, dukungan sosial keluarga mampu berfungsi dengan berbagai kepandaian dan akal. Sebagai akibatnya, hal ini akan meningkatkan kesehatan dan adaptasi keluarga.

Hal tersebut senada dengan yang diuraikan oleh Padila (2013) faktor lain yang dihadapi para lanjut usia yang sangat mempengaruhi kesehatan jiwa mereka salah satunya adalah penurunan kondisi fisik : misalnya tenaga berkurang, energi menurun, kulit makin keriput, gigi makin rontok, tulang makin rapuh dan sebagainya. Secara umum kondisi fisik seseorang yang sudah memasuki masa lansia mengalami penurunan secara berlipat ganda. Hal ini semua dapat menimbulkan gangguan atau kelainan fungsi fisik, psikologik maupun sosial, yang selanjutnya dapat menyebabkan suatu keadaan ketergantungan kepada orang lain.

Dari uraian tersebut memberikan gambaran bahwa peran dan fungsi keluarga sangat besar. Khususnya bagi lansia yang mulai banyak mengalami masalah baik fisik maupun psikologis akibat sakit atau ditinggalkan pasangannya, keluarga menjadi support system yang penting.

Hasil uji dengan Pearson Corelation diperoleh nilai, $p=0.000$ yang berarti 
terdapat hubungan yang signifikan antara kejadian depresi pada lansia dengan dukungan keluarga dan diperoleh nilai $r=-0.559$ yang berarti memiliki korelasi yang kuat dan memberikan makna berkebalikan yang berarti semakin tinggi dukungan keluarga maka semakin rendah kejadian depresi pada lansia atau sebaliknya semakin rendah dukungan keluarga semakin tinggi kejadian depresi pada lansia. Hal ini semakin memperkuat bahwa dukungan keluarga menjadi faktor yang berkontribusi terjadinya depresi pada lansia, dimana lansia dengan dukungan keluarga baik, potensi terjadinya depresi lebih rendah dibandingkan dengan lansia tanpa atau dengan dukungan keluarga yang kurang. Pada penelitian ini diperoleh informasi juga bahwa terdapat 3 responden yang tidak tinggal dengan keluarga atau tinggal sendiri saja. Dari 3 responden tersebut seluruhnya mengalami depresi ringan.

Hasil penelitian ini sesuai dengan penelitian sebelumnya yang dilakukan Dani, Yaunin dan Edison (2012) yang mendapatkan hasil terdapat hubungan yang signifikan antara dukungan keluarga dengan kejadian depresi pada usia tua di Nagari Tanjung Banai Aur, Kecamatan Sumpur Kudus, Kabupaten Sijunjung dengan nilai $p$ $=0.005$. Penelitian lain yang dilakukan Wulandari (2010), juga diperoleh hasil melalui uji Kendall $\mathrm{Tau}$ yaitu hubungan antara dukungan keluarga dengan tingkat depresi lansia adalah 0,0001. Sehingga dapat diambil kesimpulan bahwa ada hubungan yang signifikan antara dukungan keluarga dengan tingkat depresi pada lansia di Desa Kedungwaduk Karangmalang Sragen.

Hal ini juga senada dengan penelitian yang dilakukan Permana (2013), yang diperoleh hasil terdapat hubungan antara dukungan sosial keluarga dan tingkat stres pada andropause lansia di Puskesmas Patrang, Jember dengan nilai $p$ adalah $0.000<0.05$. Penelitian lain yang dilakukan Prabowo (2016), diperoleh hasil bahwa ada perbedaan tingkat depresi lansia wanita yang tinggal bersama keluarga di Kelurahan Wirogunan dengan tinggal di Panti Wredha Hanna Yogyakarta, $p$-value $=0.033(<0.05)$, lansia wanita yang tinggal dengan keluarga memiliki tingkat depresi yang lebih rendah.

Akan tetapi disisi yang lain dari hasil tabulasi silang pada tabel 5 diperoleh informasi bahwa 48 responden $(80 \%)$ dalam kondisi normal, 33 (55\%) responden dengan dukungan keluarga baik, namun sisanya 15 (25\%) responden dengan dukungan keluarga yang kurang. Dari temuan data ini membuktikan bahwa cukup banyak faktor yang mempengaruhi tingkat depresi pada lansia. Tidak serta merta dengan dukungan yang kurang menjadikan seorang lansia depresi.

Adapun menurut Padila (2013), beberapa faktor yang dihadapi para lanjut usia yang sangat mempengaruhi kesehatan jiwa lansia meliputi : penurunan kondisi fisik, penurunan fungsi dan potensial seksual, perubahan yang berkaitan dengan pekerjaan, perubahan dalam peran sosial di masyarakat, perubahan stabilitas emosi. Hal ini ditunjukkan dalam penelitian ini, dimana 35 responden dengan dukungan keluarga yang baik 2 $(5.7 \%)$ diantaranya mengalami depresi ringan yang kemungkinan disebabkan faktor-faktor yang lain tersebut. Akan tetapi faktor-faktor yang lain tersebut tidak diteliti pada penelitian ini. 


\section{KESIMPULAN}

1. Dukungan keluarga kategori baik yaitu $58.3 \%$ sedangkan $41.7 \%$ dengan dukungan yang kurang.

2. Mayoritas responden dalam kategori normal sebesar $80 \%$, sedangkan yang mengalami depresi ringan sebesar $20 \%$.

3. Terdapat hubungan yang signifikan antara dukungan keluarga dengan kejadian depresi pada lansia (nilai $p=$ $0.000 ; r=-0.559)$ dimana semakin tinggi dukungan keluarga maka semakin rendah kejadian depresi pada lansia atau sebaliknya.

\section{SARAN}

1. Bagi masyarakat, terutama yang memiliki anggota keluarga usia lansia hendaknya memberikan perhatian dan dukungan kepada mereka untuk prevensi terjadinya depresi atau mencegah depresi menjadi semakin parah.

2. Perawat khususnya dalam lingkup komunitas dapat lebih meningkatkan perannya terutama mengedukasi masyarakat terkait upaya kesehatan jiwa masyarakat khususnya pada lansia.

3. Bagi peneliti selanjutnya dapat melakukan penelitian faktor yang lain yang menyebabkan depresi pada lansia, seperti penurunan kondisi fisik, penurunan fungsi dan potensial seksual, perubahan yang berkaitan dengan pekerjaan, perubahan dalam peran sosial di masyarakat, perubahan stabilitas emosi.

\section{DAFTAR PUSTAKA}

Aspiani, R.Y. 2014. Buku Ajar Asuhan Keperawatan Gerontik Jilid 1. Trans Info Media, Jakarta.

Dani, F.P., Y. Yaunin, dan E. Edison. 2012. 'Hubungan Dukungan Keluarga dengan Kejadian Depresi pada Usia
Tua di Nagari Tanjung Banai

Aur, Kecamatan Sumpur

Kudus, Kabupaten Sijunjung

Tahun 2012".

http://jurnal.fk.unand.ac.id.

Diakses 10 Desember 2017.

Hawari, D. 2016. Manajemen Stress Cemas dan Depresi. FKUI, Jakarta.

Irawan, H. 2013. Gangguan Depresi pada Lanjut Usia. Diakses pada tanggal 10 Januari 2018, http://www.kalbemed.socialres earchmethods.net/kb/index.ht $\mathrm{m}$.

Kurniasari, N.D. 2014. "FaktorFaktor yang Berhubungan dengan Depresi pada Lansia di Dusun Kalimanjing Amnar Ketawang Gamping Sleman Yogyakarta".

repository.umy.ac.id. Diakses 15 Januari 2018.

Marchira, C. dan R. Wirasto. 2007. "Pengaruh Faktor-Faktor Psikososial Dan Insomnia Terhadap Depresi Pada Lansia Di Kota Yogyakarta". https://journal.ugm.ac.id.

Diakses 10 Januari 2018.

Maryam, R.S, et al. 2008. Mengenal Usia Lanjut dan Perawatannya. Salemba Medika, Jakarta.

Padila. 2013. Keperawatan Gerontik. Nuha Medika, Yogyakarta.

Permana, C.A. 2013. Hubungan Dukungan Sosial Keluarga Dengan Tingkat Stres Pada Lansia Andropause. Skripsi. http://repository.unej.ac.id. Diakses 15 Januari 2018

Prabowo, J. 2016. "Perbedaan Tingkat Depresi Lansia Wanita Yang Tinggal Bersama Keluarga Di Kelurahan Wirogunan Dengan Tinggal Di Panti Wredha Hanna Yogyakarta". nursingjurnal.respati.ac.id. Diakses 12 Januari 2018. 
Priyoto. 2014. Konsep Manajemen Stress. Nuha Medika, Yogyakarta.

Setiadi. 2008. Konsep dan Proses Keperawatan Keluarga. Graha Ilmu, Yogyakarta.

Widyanto, F.C. 2014. Keperawatan Komunitas dengan Pendekatan Praktis. Nuha Medika, Yogyakarta.

Wulandari, C. F .2010. Hubungan Antara Dukungan Keluarga Dengan Tingkat Depresi Pada Lansia Di Desa Kedungwaduk Karangmalang Sragen. Thesis, Universitas Muhammadiyah Surakarta. http://eprints.ums.ac.id. Diakses 10 Januari 2018

${ }^{1}$ Dosen Akper Panti Kosala

Surakarta

${ }^{2}$ Mahasiswa Akper Panti Kosala

Surakarta 